\title{
The diversity of methodologies applied in Indonesian journal articles focused on biochemistry learning
}

\author{
Poncojari Wahyono a,1,* , Fefi Eka Wardiani b,2, Eko Susetyarini a,3 \\ a Department of Biology Education, Faculty of Teacher Training and Education, Universitas Muhammadiyah Malang, Jl. Raya \\ Tlogomas 246, Malang, East Java 65144, Indonesia \\ b Life Science Faculty, National Chiayi University, Taiwan No. 300, Xuefu Road, East District Chiayi City, 60004, Taiwan \\ poncojari@umm.ac.id *; 2 fefieka97@gmail.com; ${ }^{3}$ susetyorini@umm.ac.id \\ * Corresponding author
}

\begin{tabular}{|c|c|}
\hline ARTICLE INFO & ABSTRACT \\
\hline $\begin{array}{l}\text { Article history } \\
\text { Received January 30, } 2020 \\
\text { Revised February 24, } 2020 \\
\text { Accepted February 29, } 2020 \\
\text { Published March 31, } 2020 \\
\text { Keywords } \\
\text { Biochemistry learning } \\
\text { Methodology diversity } \\
\text { Research methodology }\end{array}$ & $\begin{array}{l}\text { Biochemistry is a study which consists of many difficult concepts. Research that } \\
\text { examines biochemistry learning needs to be continuously carried out so that the quality } \\
\text { of learning can be evaluated and improved. Hence, this content analysis addressed to } \\
\text { analyze the research methodologies of the articles published in various Indonesian } \\
\text { biology education journals. The focus of the articles studied was biochemistry learning } \\
\text { in Indonesia. To go further, the articles must be published between } 2000 \text { and } 2020 \text {. The } \\
\text { findings of this study informed that during the last two decades, the research } \\
\text { publications which examined biochemistry learning have rarely been carried out. From } \\
\text { those publications, quantitative research was the research type used the most. In } \\
\text { addition, postgraduate student was the most frequently chosen as the research subject. } \\
\text { Furthermore, questionnaire sheet was the highest preference of data collection } \\
\text { instrument used. Meanwhile, the highest frequency of data analysis methods used were } \\
\text { percentage and N-gain calculation. The low number of publications and the lack of } \\
\text { research methodology diversity need to be more seriously considered by increasing the } \\
\text { number of studies examining biochemistry learning in Indonesia. } \\
\text { This is an open access article under the CC-BY-SA license } \\
\text { a }\end{array}$ \\
\hline $\begin{array}{l}\text { How to cite: Wahyono, } \\
\text { articles focu } \\
22219 / \text { jpbi. }\end{array}$ & $\begin{array}{l}\text { E., \& Susetyarini, E. (2020). The diversity of methodologies applied in Indonesian journ } \\
\text { mistry learning. JPBI (Jurnal Pendidikan Biologi Indonesia), 6(1), 1-8. doi: https://doi.org/1 }\end{array}$ \\
\hline
\end{tabular}

\section{INTRODUCTION}

Biochemistry involved branch of biology that is urgent to learn. Various biological concepts and phenomena can arise in nature due to biochemical processes (DeBerardinis \& Thompson, 2012). The reason, metabolism, as one of the main characteristics of living things, is studied in biochemistry (Rabinowitz \& Vastag, 2012). Metabolism occurs in cells (Yang, 2016) and cells are smallest unit of organisms (Chung, Cha, Lee, Park, \& Lee, 2017). Not surprisingly, understanding biochemical concepts will determine one's understanding of concepts in other biological disciplines.

Unfortunately, biochemistry is considered as one discipline that difficult to learn (Tibell \& Rundgren, 2010). This statement is based on several studies that have mapped difficult concepts in biology. These difficulties are not only found in high school students (Hadiprayitno, Muhlis, \& Kusmiyati, 2019), but up to college students ( $\mathrm{H}$. 
Chen \& Ni, 2013; Wahyudi, Liliasari, Supriyanti, \& Nahadi, 2019). Furthermore, difficulties in studying biochemistry are not only problems faced by students abroad ( $\mathrm{H}$. Chen \& Ni, 2013), but also in Indonesia (Hadiprayitno et al., 2019; Wahyudi et al., 2019).

To minimize learning difficulties, various studies were conducted. These studies have identified difficult concepts in biochemistry. There are also studies that focus on implementing certain learning form to optimize biochemical learning (Kulak \& Newton, 2014; Yu, Yi, Zhai, \& Wang, 2017). On the other hand, several other studies have attempted to examine the relationship of various variables involved in biochemical learning (McRae, 2010; Ojennus, 2016).

In Indonesia, various studies examining biochemical learning have also been carried out, particularly in the context of biology learning. Some studies have focused their studies on improving the various competencies of students when studying biochemistry. Some of these competencies include psychomotor skills (Pusipitasari \& Febrianti, 2018), scientific work ability (Widyaningrum \& Wijayanti, 2019), problem solving skill (Lismaya, 2017), as well as students' affective learning outcomes (Widyaningrum \& Wijayanti, 2017). Other studies have focused their studies to analyze the correlation of several variables in biochemical learning (Pusipitasari \& Febrianti, 2018). In addition, some other researchers conduct development research activities to improve the quality of biochemical learning. Some of these developments, such as the development of teaching materials (Brahmana \& Astitiasih, 2017) to the manual for practical activities (Widyaningrum \& Wijayanti, 2018). However, from various studies in biochemical learning in Indonesia, there has not been a single study that examines trends in the use of research methodologies in that field.

Research that examining research methodologies trend is important because it can provide information about the distribution and variation of research forms that have been carried out in Indonesia. In addition, such research can also provide comprehensive information about research developments in biochemical learning. The information obtained can be used as a basis for policy and a basis for improving the quality of learning, as well as input for further research. Therefore, through content analysis on various biology education scientific articles published in Indonesia from 2000 to 2020, the purpose of this research was to obtain information about the diversity of research methods from various studies examining biochemical learning in Indonesia.

\section{METHOD}

This research was a content analysis conducted on research articles that have been published in various scientific journals in Indonesia. The data obtained in this study came from the results of content analysis in biology education research articles. These articles come from all biology education journals that have been registered in the Science and Technology Index (SINTA) database in February 2020. SINTA (http://sinta2.ristekdikti.go.id/) is a portal that contains measurements of scientific performance and technology developed by the Indonesian Ministry of Research, Technology and Higher Education. Next, all articles that examine biochemistry learning were collected from each journal. The articles analyzed in this study were all articles that have been published online from February 2000 to February 2020.

The instrument used in this study was a content analysis guide sheet containing aspects to be examined (Table 1). This instrument is an instrument used by Susetyarini and Fauzi (2020) and is an adaptation of Fauzi and Pradipta (2018). There were five main aspects examined in the content analysis in this study. The seven aspects, namely (1) the number of publications per year; (2) type of research; (3) research subjects; (4) data collection instruments; and (5) data analysis techniques. In the data analysis stage, each article will be determined in which category each of the aspects of the article can be classified. The determination was based on the information submitted by the author in the abstract section, methods, and discussion. The data obtained was then presented in the form of bar graphs.

Table 1. The aspects and categories used as the basis for content analysis in this study

\begin{tabular}{ll}
\hline \multicolumn{1}{c}{ Aspects } & \multicolumn{1}{c}{ Categories } \\
\hline Types of research (2a) & A.1-Research and Development (R and D) \\
& A.2-Classroom Action Research (CAR) \\
& A.3-Qualitative Research \\
& A4-Quantitative Research \\
\hline Types of quantitative research & B.1-Observation Studies (OS) \\
(2b) & B.2-Correlational Research (CR) \\
& B.3-Survey Research (SR) \\
& B.4-Pre-Experimental Designs (PED) \\
& B.5-True Experimental Designs (TED) \\
& B.6-Quasi-Experimental Designs (QED) \\
\hline
\end{tabular}




\begin{tabular}{ll}
\hline \multicolumn{1}{c}{ Aspects } & \\
\hline & B.7-Ex Post Facto Designs (EPFD) \\
\hline Research subject & C.1-VII Grade JHS students \\
C.2- VIII Grade JHS students & C.3-IX Grade JHS students \\
C.4-X Grade SHS students \\
C.5-XI Grade SHS students \\
C.6-XII Grade SHS students \\
C.7-Undergraduate students \\
C.8-Postgraduadate students \\
C.9-JHS teacher \\
C.10-SHS teacher \\
C.11-lecturer \\
\hline D.1-questionnaire sheet \\
D.2-observation sheet \\
D.3-test sheet \\
D.4-interview sheet \\
D.5-unidentified \\
E.1-mean \\
E.2-percentage \\
E.3-N-gain \\
E.4-t-test \\
E.5-ANOVA \\
E.6-ANCOVA \\
E.7- Correlation/regression \\
E.8-Unidentified \\
E.9-Others \\
\hline
\end{tabular}

\section{RESULTS AND DISCUSSION}

In this study, content analysis was carried out to analyze the various research methods used by researchers in biochemical learning. The number of publications in the field of biochemical learning from one year to the next is presented in Figure 1. Based on Figure 1, in the last two decades, research reports on biochemical learning began to be published in the period 2015 to 2019 . Besides being only found in the last five years, the number of publications only seven articles. The low number of publications is not comparable to the total research publications in biology learning in general. As reported in previous studies, research published in 18 biology journals in Indonesia until 2017 reached 122 articles (Fauzi \& Pradipta, 2018). Other research that focuses on articles that examine critical thinking skills could collect 42 articles from 13 biology education journals indexed by SINTA until 2018 (Susetyarini \& Fauzi, 2020).

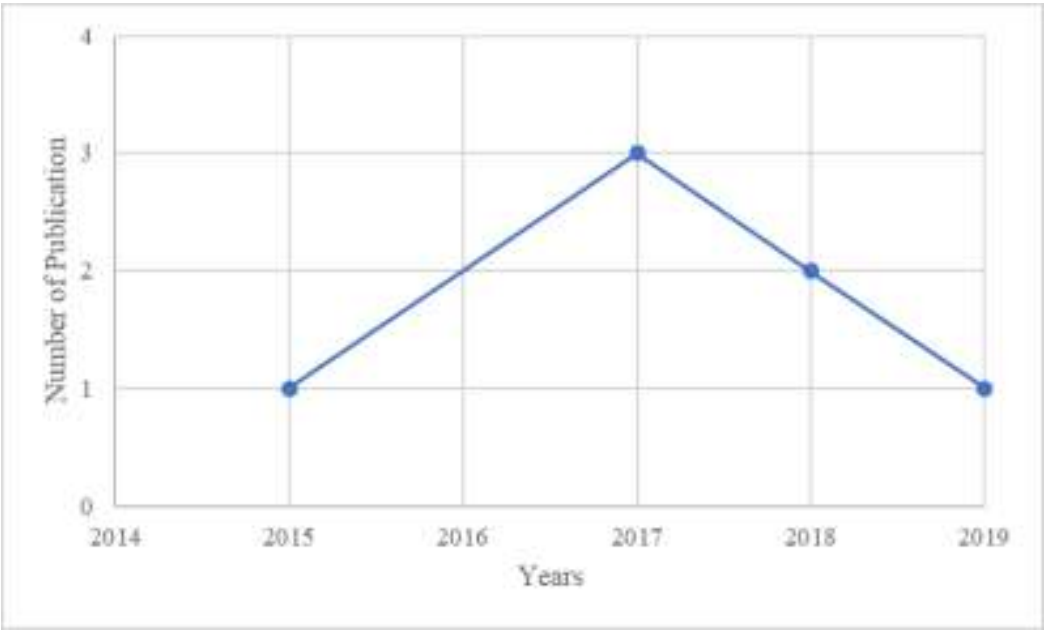

Figure 1. Trend of the number of research publications in biochemical learning in Indonesia

Furthermore, various types of research are presented in Figure 2 and Figure 3 . Figure 2 presents information about the type of research in general, while Figure 3 is more focused on studying the variety of quantitative research chosen by researchers. Based on Figure 2, quantitative research was the type of 
research most often used. These results are in line with the results of a study that specifically examines articles that report research on critical thinking skills in learning biology in Indonesia (Susetyarini \& Fauzi, 2020). This result is also in line with various other studies that have been carried out in Turkey (Goktas et al., 2012; Uzunboylu \& Asiksoy, 2014). On the other hand, no researcher has a qualitative approach. Perhaps, one of the reasons is because this type of research is more complicated in its implementation than others (Atieno, 2009; Rahman, 2016).

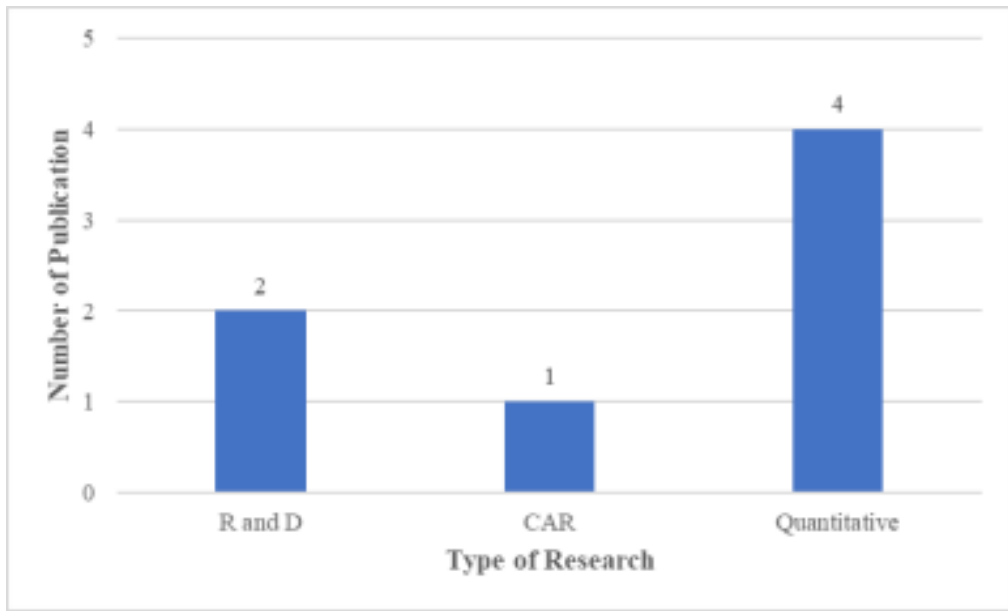

Figure 2. Types of research selected by researchers who study biochemical learning

Based on Figure 3, quasi-experimental design is the quantitative research design that is most often implemented by researchers. These results are in line with previous reports (Fauzi \& Pradipta, 2018; Susetyarini \& Fauzi, 2020). Based on the explanation in the previous report, quasi-experimental design is more often chosen by Indonesian researchers because this design is the most likely design to be applied in Indonesian conditions (Susetyarini \& Fauzi, 2020). Because, in the design of this study, researchers are not required to do random assignments (Petchko, 2018; Thye, 2014). This requirement must be met if the researcher decides to apply true-experimental design in his research (Martella, Nelson, Morgan, \& MarchandMartella, 2013).

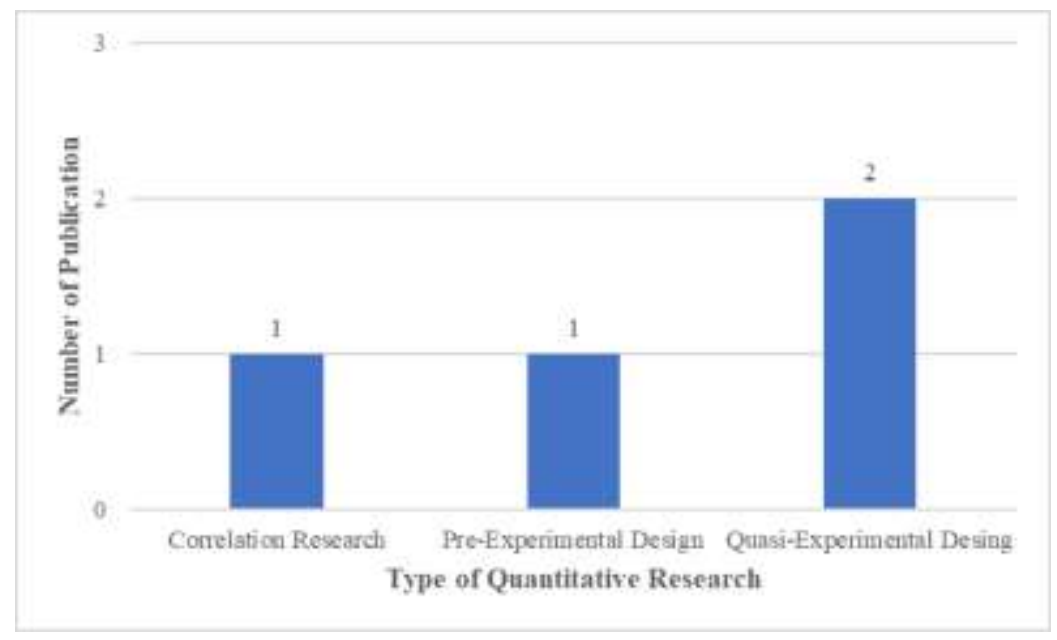

Figure 3. Variety of quantitative research designs applied by researchers in biochemical learning

Furthermore, this study also informs that the research subjects involved in research in biochemical learning are not diverse. Of the seven studies, all chose undergraduate students as their research subjects. These results indicate that research in biochemical learning in Indonesia is more often done by lecturers or graduate students than teachers or undergraduate students. This kind of information is unfortunate because many students reported having difficulty learning biochemical concepts in high school (Fauzi \& Mitalistiani, 2018; Hadiprayitno et al., 2019; Ozcan, Ozgur, Kat, \& Elgun, 2014). 
Furthermore, variations in data collection techniques were also obtained from content analysis in this study. The findings are presented in Figure 4. Based on Figure 4, the questionnaire sheet is the data collection instrument most frequently chosen by researchers. Questionnaire is a data collection instrument that is commonly used in various studies, both quantitative research, development research, classroom action research, to qualitative research. Not surprisingly, the number of publications that use this instrument is more than any other instrument. Questionnaire can measure student attitudes and measure the quality of learning products that have been developed. After the questionnaire, the test sheet is the second instrument most frequently used by researchers in biochemical learning. The test is an instrument that is able to measure students' cognitive abilities. This instrument is commonly used in quantitative research.

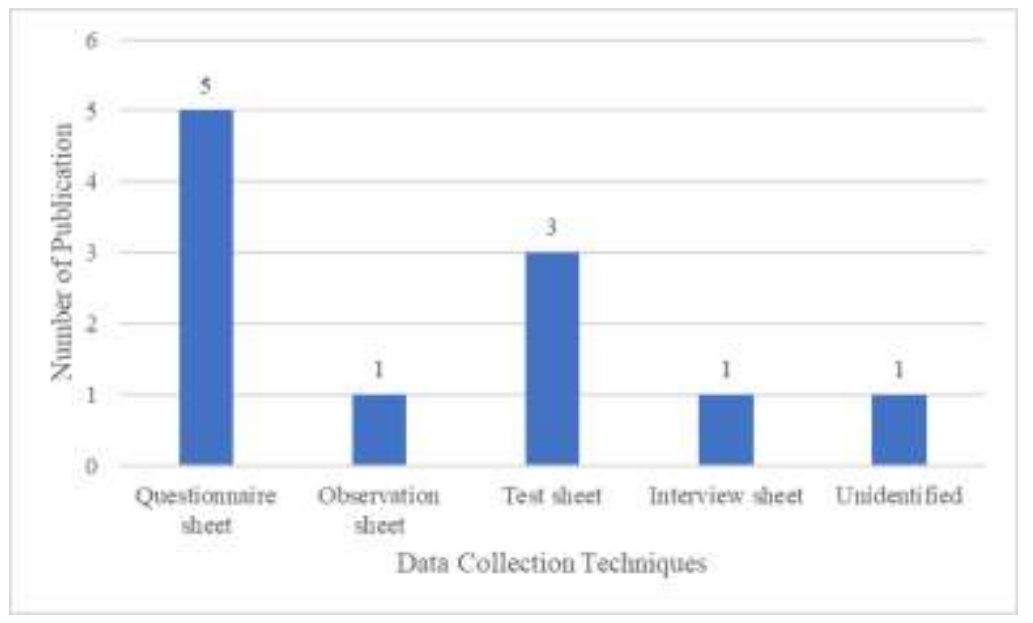

Figure 4. Variations in the use of data collection techniques in research in biochemical learning

Finally, a variety of data analysis techniques used by researchers are presented in Figure 5 . Based on Figure 5, percentages and $\mathrm{N}$-gain were the two data analysis techniques most frequently chosen by researchers. Percentages include descriptive statistical analysis techniques that are able to describe the proportion of certain criteria in the data set that has been collected. Percentages are commonly used to see student performance and the quality of learning products developed in research development. On the other hand, $\mathrm{N}$-gain is a data analysis technique that is able to measure the magnitude of the intervention given to the dependent variable that is the focus of the study. This analysis is commonly used in various experimental studies.

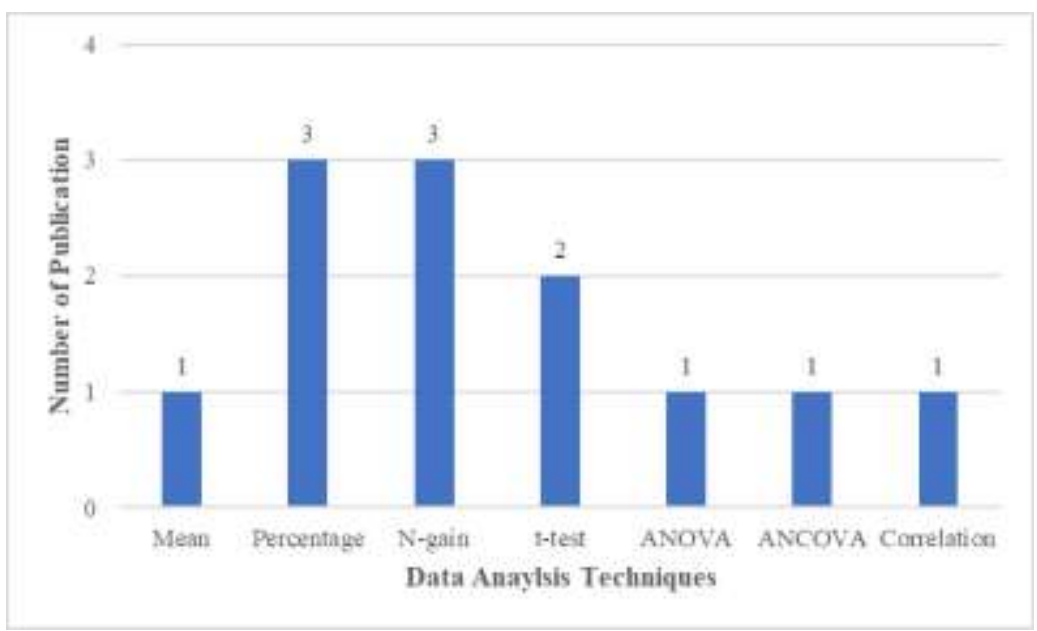

Figure 5. Data analysis techniques used by researcher in biochemistry learning

The results of the analysis that have been done show that the variety of research methods in biochemical learning is not very high. The low number of publications is a major factor causing this condition. This condition is different from research conditions in various countries. With the emergence of various publications in biology learning, researchers in various countries are able to develop various learning innovations that are expected to be able to optimize the biochemical learning process (Cicuto, Pazinato, \& Torres, 2019; Kulak \& Newton, 2014; 
Yu et al., 2017). Furthermore, biochemistry studies various fundamental concept underlying several phenomena in biology (DeBerardinis \& Thompson, 2012). Biochemistry also studies various concepts that underlie the development of applied biology (B.-S. Chen \& Li, 2017). The implication, an understanding of biochemistry will determine how broad a person's understanding of biology as a whole. Therefore, research with various methodologies aimed at improving the quality of biochemical learning is highly recommended to be improved.

In connection with the results obtained, the form of research not found in the publications that have been analyzed is qualitative research. Although this type of research is more complicated than quantitative research (Atieno, 2009; Rahman, 2016), the benefits of this study are no less great than other types of research. Through qualitative research, researchers can get a deeper understanding of certain learning phenomena (Aspers \& Corte, 2019; Austin \& Sutton, 2014). In addition, this type of research allows researchers to evaluate the biochemical learning process that has been implemented in Indonesia more comprehensively.

In addition, research aimed at exploring high-level skills in biochemical learning was also difficult to find. Various publications only limit their dependent variables to cognitive learning outcomes for which the cognitive level is not clearly informed. Higher-order thinking skills are the main competencies that must be mastered in the 21st Century (Budsankom, Sawangboon, Damrongpanit, \& Chuensirimongkol, 2015; Greiff, Niepel, \& Wüstenberg, 2015). Students are expected to be able to think critically, creatively, be able to solve problems, and have metacognition to face global challenges (Dwyer, Hogan, \& Stewart, 2014; Gregory, Hardiman, Yarmolinskaya, Rinne, \& Limb, 2013; Havenga et al., 2013; Reeve, 2016; Wall, 2015). They also need to have good analytical and evaluation skills. If learning is only intended to increase understanding and the number of memorizing concepts, students will have difficulty applying the knowledge they can when facing problems in the real world. Therefore, further studies in learning biology in Indonesia are expected to be able to examine students' higher-order thinking skills in biochemical learning, both from profiling to researching the effects of certain forms of learning and learning products.

\section{CONCLUSION}

The findings of this study inform that during the last two decades, research publications examining biochemical learning have rarely been carried out. From these publications, quantitative research is the type of research most often used. Postgraduate is the most frequently chosen research subject. Furthermore, questionnaire sheets and percentages and $\mathrm{N}$-gain are the most commonly used data collection instruments and data analysis methods. Based on the low number of publications and various research methodologies, researchers in Indonesia are advised to increase the frequency of their research in biochemical learning. Since biochemistry is a biological discipline that is difficult to study, research aimed at optimizing the biochemical learning process is highly recommended to be carried out.

\section{REFERENCES}

Aspers, P., \& Corte, U. (2019). What is qualitative in qualitative research. Qualitative Sociology, 42(2), 139160. doi: https://doi.org/10.1007/s11133-019-9413-7

Atieno, O. P. (2009). An analysis of the strengths and limitation of qualitative and quantitative research paradigms. Problems of Education in the 21st Century, 13, 13-18. Retrieved from http://www. scientiasocialis.It/pec/files/pdf/Atieno_Vol.13.pdf

Austin, Z., \& Sutton, J. (2014). Qualitative research: Getting started. The Canadian Journal of Hospital Pharmacy, 67(6), 436-440. doi: https://doi.org/10.4212/cjhp.v67i6.1406

Brahmana, E. M., \& Astitiasih, I. A. R. (2017). Pengembangan bahan ajar biokimia berbasis hasil penelitian identifikasi kandungan asam amino pada rumput laut (Dictyota patens) di Pantai Segara Sanur. Jurnal Pendidikan Biologi Indonesia, 3(2), 160-165. doi: https://doi.org/10.22219/jpbi.v3i2.4036

Budsankom, P., Sawangboon, T., Damrongpanit, S., \& Chuensirimongkol, J. (2015). Factors affecting higher order thinking skills of students: A meta-analytic structural equation modeling study. Educational Research and Reviews, 10(19), 2639-2652. doi: https://doi.org/10.5897/ERR2015

Chen, B.-S., \& Li, C.-W. (2017). Big drug design mechanisms via systems biology and big database mining. In Big Mechanisms in Systems Biology (pp. 737-845). Elsevier. doi: https://doi.org/10.1016/B978-0-12809479-2.00012-3

Chen, H., \& Ni, J.-H. (2013). Teaching arrangements of carbohydrate metabolism in biochemistry curriculum 
in Peking University Health Science Center. Biochemistry and Molecular Biology Education, 41(3), 139 144. doi: https://doi.org/10.1002/bmb.20695

Chung, S., Cha, S., Lee, S.-Y., Park, J.-H., \& Lee, S. (2017). The five elements of the cell. Integrative Medicine Research, 6(4), 452-456. doi: https://doi.org/10.1016/j.imr.2017.10.002

Cicuto, C., Pazinato, M., \& Torres, B. (2019). Teaching metabolism with scientific articles: A new approach. Biochemistry and Molecular Biology Education, 47(1), 85-92. doi: https://doi.org/10.1002/bmb.21187

DeBerardinis, R. J., \& Thompson, C. B. (2012). Cellular metabolism and disease: What do metabolic outliers teach us? Cell, 148(6), 1132-1144. doi: https://doi.org/10.1016/j.cell.2012.02.032

Dwyer, C. P., Hogan, M. J., \& Stewart, I. (2014). An integrated critical thinking framework for the 21st century. Thinking Skills and Creativity, 12, 43-52. doi: https://doi.org/10.1016/j.tsc.2013.12.004

Fauzi, A., \& Mitalistiani. (2018). High school biology topics that perceived difficult by undergraduate students. Didaktika Biologi: Jurnal Penelitian Pendidikan Biologi, 2(2), 73-84. Retrieved from http://jurnal.umpalembang.ac.id/dikbio/article/download/1242/1067

Fauzi, A., \& Pradipta, I. W. (2018). Research methods and data analysis techniques in education articles published by Indonesian biology educational journals. JPBI (Jurnal Pendidikan Biologi Indonesia), 4(2), 123-134. doi: https://doi.org/10.22219/jpbi.v4i2.5889

Goktas, Y., Hasancebi, F., Varisoglu, B., Akcay, A., Bayrak, N., Baran, M., \& Sozbilir, M. (2012). Trends in educational research in Turkey: A content analysis. Educational Sciences: Theory \& Practice, 12(1), 455-460. Retrieved from https://files.eric.ed.gov/fulltext/EJ978453.pdf

Gregory, E., Hardiman, M., Yarmolinskaya, J., Rinne, L., \& Limb, C. (2013). Building creative thinking in the classroom: From research to practice. International Journal of Educational Research, 62, 43-50. doi: https://doi.org/10.1016/j.ijer.2013.06.003

Greiff, S., Niepel, C., \& Wüstenberg, S. (2015). 21st century skills: International advancements and recent developments. Thinking Skills and Creativity, 18, 1-3. doi: https://doi.org/10.1016/j.tsc.2015.04.007

Hadiprayitno, G., Muhlis, \& Kusmiyati. (2019). Problems in learning biology for senior high schools in Lombok Island. In Journal of Physics: Conference Series (Vol. 1241, p. 012054). IOP Publishing. doi: https://doi.org/10.1088/1742-6596/1241/1/012054

Havenga, M., Breed, B., Mentz, E., Govender, D., Govender, I., \& Dignum, F. (2013). Metacognitive and problem-solving skills to promote self-directed learning in computer programming: Teachers' experiences. SA-EDUC Journal, 10(2), 1-14. Retrieved from http://www.nwu.ac.za/sites/www.nwu.ac. za/files/files/p-saeduc/sdl issue/Havenga et al. Metacognitive and problem-solving skills to .pdf

Kulak, V., \& Newton, G. (2014). A guide to using case-based learning in biochemistry education. Biochemistry and Molecular Biology Education, 42(6), 457-473. doi: https://doi.org/10.1002/bmb.20823

Lismaya, L. (2017). Penerapan pembelajaran biokimia berbasis student center learning (SCL) terhadap kemampuan pemecahan masalah mahasiswa. BieEDUIN: Jurnal Program Studi Pendidikan Biologi, 7(1). Retrieved from https://journal.uinsgd.ac.id/index.php/bioeduin/article/view/2752

Martella, R. C., Nelson, J. R., Morgan, R. L., \& Marchand-Martella, N. E. (2013). Understanding and interpreting educational research. New York: The Guilford Press. Retrieved from https://books.google. co.id/books/about/Understanding_and_Interpreting_Education.html?id=6P5CFqOFUHcC\&redir_esc=y

McRae, M. P. (2010). Correlation of preadmission organic chemistry courses and academic performance in biochemistry at a Midwest Chiropractic Doctoral Program. Journal of Chiropractic Education, 24(1), 30 34. doi: https://doi.org/10.7899/1042-5055-24.1.30

Ojennus, D. D. (2016). Assessment of learning gains in a flipped biochemistry classroom. Biochemistry and Molecular Biology Education, 44(1), 20-27. doi: https://doi.org/10.1002/bmb.20926

Ozcan, T., Ozgur, S., Kat, A., \& Elgun, S. (2014). Identifiying and comparing the degree of difficulties biology subjects by adjusting it is reasons in elemantary and secondary education. In Procedia - Social and Behavioral Sciences (Vol. 116, pp. 113-122). Elsevier B.V. doi: https://doi.org/10.1016/j.sbspro.2014. 01.177

Petchko, K. (2018). Research in public Policy and economics. In How to Write About Economics and Public Policy (pp. 19-39). Elsevier. doi: https://doi.org/10.1016/B978-0-12-813010-0.00002-8

Pusipitasari, E. D., \& Febrianti, N. (2018). Analisis keterampilan psikomotorik mahasiswa pada praktikum biokimia dan korelasinya dengan hasil belajar kognitif. Jurnal Pendidikan Biologi, 8(1), 31-38. doi: https://doi.org/10.24114/jpb.v8i1.11664

Rabinowitz, J. D., \& Vastag, L. (2012). Teaching the design principles of metabolism. Nature Chemical Biology, 8(6), 497-501. doi: https://doi.org/10.1038/nchembio.969 
Rahman, M. S. (2016). The advantages and disadvantages of using qualitative and quantitative approaches and methods in language "testing and assessment" research: A literature review. Journal of Education and Learning, 6(1), 102. doi: https://doi.org/10.5539/jel.v6n1p102

Reeve, E. M. (2016). 21st century skills needed by students in technical and vocational education and training. Asian International Journal of Social Sciences, 16(4), 62-74. doi: https://doi.org/10.29139/ aijss.20160404

Susetyarini, E., \& Fauzi, A. (2020). Trend of critical thinking skill researches in biology education journals across Indonesia: From research design to data analysis. International Journal of Instruction, 13(1), 535-550. doi: https://doi.org/10.29333/iji.2020.13135a

Thye, S. R. (2014). Logical and philosophical foundations of experimental research in the social sciences. In Laboratory Experiments in the Social Sciences (pp. 53-82). Elsevier. doi: https://doi.org/10.1016/B9780-12-404681-8.00003-0

Tibell, L. A. E., \& Rundgren, C.-J. (2010). Educational challenges of molecular life science: Characteristics and implications for education and research. CBE-Life Sciences Education, 9(1), 25-33. doi: https:/l doi.org/10.1187/cbe.08-09-0055

Uzunboylu, H., \& Asiksoy, G. (2014). Research in physics education : A study of content analysis. Procedia Social and Behavioral Sciences 136, 136, 425-437. doi: https://doi.org/10.1016/j.sbspro.2014.05.353

Wahyudi, A., Liliasari, S., Supriyanti, T., \& Nahadi, N. (2019). Biochemistry course achievement of pre-service chemistry teachers at one of Islamic institution of teachers training program in Bandung. In Journal of Physics: Conference Series (Vol. 1157, p. 042020). doi: https://doi.org/10.1088/1742-6596/1157/4/042 020

Wall, T. F. (2015). The transferability of higher order cognitive skills. In Procedia - Social and Behavioral Sciences (Vol. 174, pp. 233-238). Elsevier B.V. doi: https://doi.org/10.1016/j.sbspro.2015.01.652

Widyaningrum, D. A., \& Wijayanti, T. (2017). Pemberdayaan hasil belajar afektif mahasiswa melalui model pembelajaran search, solve, create, and share (SSCS) berbantuan media video. Didaktika Biologi: Jurnal Penelitian Pendidikan Biologi, 1(2), 105-112. Retrieved from http://jurnal.um-palembang.ac.id/ dikbio/article/view/679/613

Widyaningrum, D. A., \& Wijayanti, T. (2018). Developing of guided inquiry-based biochemistry practicum guidebook. JPBI (Jurnal Pendidikan Biologi Indonesia), 4(3), 209-214. doi: https://doi.org/10.22219/ jpbi.v4i3.6857

Widyaningrum, D. A., \& Wijayanti, T. (2019). Implementasi buku petunjuk praktikum biokimia berbasis inkuiri terbimbing untuk meningkatkan kemampuan kerja ilmiah. Edubiotik: Jurnal Pendidikan, Biologi Dan Terapan, 4(2), 58-67. doi: https://doi.org/10.33503/ebio.v4i02.437

Yang, P. L. (2016). Metabolomics and lipidomics. In Viral Pathogenesis (pp. 181-198). Elsevier. doi: https://doi.org/10.1016/B978-0-12-800964-2.00014-8

Yu, L., Yi, S., Zhai, J., \& Wang, Z. (2017). Approaches to enhance the teaching quality of experimental biochemistry for MBBS students in TSMU, China. Biochemistry and Molecular Biology Education, 45(4), 360-364. doi: https://doi.org/10.1002/bmb.21050 